\title{
Terör Yönetimi Kuramı (Dehşet Yönetimi Kuramı)
}

\author{
Terror Management Theory
}

\section{Berrin BULUT*}

Öz: Terör Yönetimi Kuramı iki temel hipoteze dayanmaktadır. Bunlar kaygı tamponu ve ölümlülüğün belirginleşmesi hipotezidir. Kurama göre bireyin ölümlülüğünün hatırlatılması ona kaygı vermektedir. Birey bu kaygıyı azaltmak için benlik saygısını yükseltmeye çalışmakta veya kültürel dünya görüşlerine bağlanmaktadır. Bu çalışmada, terör yönetimi kuramının tarihçesi, kavramları ve varsayımları ele alınmıştır. Bu kapsamda, Türkiye'de yapılmış olan 17 çalışma analiz edilmiştir. Bulgular, 2'si kısmi olmak üzere 12 çalışmanın terör yönetimi kuramını desteklediğini ve 2 çalışmanın kuramı desteklemediğini göstermektedir. Kalan 3 çalışma ise terör yönetimi kapsamındaki diğer çalışmalar başlığı altında ele alınmıştır. Terör yönetimine ilişkin teorik bilgilerin ardından Türkiye'de bu alanda konuya ilişkin yapılmış olan çalışmaların sonuçları bütünleştirilerek 12 çalışma üzerinde meta analiz yapılmıştır. Rastgele etkiler modeline göre toplam etki büyüklüğü $0,161(0,125$ standart hata ve güven aralığı \%95, alt sınır -0,083 ve üst sınır 0,407) olarak saptanmıştır. Sonuçlar ilgili literatür temelinde tartışılmıştır.

Anahtar sözcükler: Terör (Dehşet) Yönetimi, Ölümlülük, Ölüm Kaygısı, Etki Büyüklüğü

Abstract: Terror Management Theory is based upon two main hypotheses. These are the anxiety buffer and the mortality salience hypothesis. According to the theory, the salience of mortality raises the anxiety of the individual. The individual in consequence raises his/her self-esteem or validates his/her cultural worldview as a buffer against this anxiety. In this study, the history, concepts and assumptions of terror management theory are discussed. Within this context 17 studies were analysed. 10 of these studies support, 2 of them partly support and 2 of them did not support terror management theory. The remaining 3 studies are discussed under the 'other studies' title. Following the theoretical information regarding terror management theory, the results of the studies conducted in Turkey are integrated and with 12 studies, meta-analysis was performed. According to the random effects model, the total effect size is $0,161(0,125$ standard error and $95 \%$ confidence interval, the lower limit is -0.083 and upper limit is $0,407)$. The results of this study are discussed on the basis of the relevant literature.

Keywords: Terror Management, Mortality, Death Anxiety, Effect Size

\section{Giriş}

Çağdaş sosyal psikoloji literatürü günümüzde, insan davranışlarını kültürel ve tarihi bir bağlamda yeterli derecede açıklayabilecek, düzenleyebilecek ve deneysel sosyal psikoloji alanında mevcut deneysel çalışmaları bütünleştirebilecek kuramsal bir anlayışı içermemektedir. Aynı zamanda gelecekteki araştırmaları yönlendirebilecek ve bireysel ve sosyal değişimler için yararlı bilgiler sağlayabilecek bir anlayışa sahip değildir. Böyle bir anlayışa doğru çalışma çabası içerisinde, sosyal davranışın terör yönetimi kuramı 1980'lerde Greenberg, Solomon ve Pyszczynski tarafından geliştirilmiştir.

\footnotetext{
* Arş. Gör., Ahi Evran Üniversitesi, Fen-Edebiyat Fakültesi, Psikoloji Bölümü, Kırşehir. berrin_teke@yahoo.com.
} 
Terör yönetimi kuramı büyük ölçüde Ernst Becker'1n (1962, 1973, 1975 akt. Greenberg, Pyszczynski, Solomon, Rosenblatt, Veeder, Kirkland \& Lyon 1990) çeşitli sosyal bilimler disiplinlerini, insan sosyal davranışının genel bir teorisine sentezleme girişimlerinden ortaya çıkmıştır. Becker'a göre gelişmiş insanın entelektüel yetenekleri, onun güvenlik açığına ve nihai ölümün bilincine varmasına neden olmaktadır.

En temel insan güdüsü yaşamı sürdürmek için duyulan istektir. Tüm özel güdüler bu temel evrimsel uyuma dayanmaktadır. İnsanlar kendileri ve ait oldukları gruplar hakkında olumlu değerlendirmeler elde etmeye güdülenmişlerdir. İnsanlar diğer canlılar gibi kendilerini koruma temel içgüdüsüne sahiptirler. Buna rağmen, insanların entelektüel yeteneğe sahip olmaları onları diğer canlılardan ayırmaktadır. $\mathrm{Bu}$ da onlara ölümün kaçınılmazlığının farkında olmalarını açıkça ve acı verici bir şekilde göstermektedir. Bundan dolayı insanlar en temel ihtiyaçlarının ve arzularının sonuçta yitirilebileceği bilgisi ile yaşamak zorundadırlar (Pyszczynski, Greenberg \& Solomon 1997).

İnsanlar için gelecekteki olası olayları (özellikle acı veren ve trajik olayları) hayal edebilme yeteneği, olası bir kaygının sürekli kaynağıdır. Olumsuz olayların meydana gelebileceğini bilmek, bireyin bu tür sonuçlardan korunabileceğini güvence altına alma ihtiyacını yaratmaktadır. Böyle bir güvence olmadan bireyler felç edici bir terör deneyimlemektedirler (Solomon, Greenberg \& Pyszczynski 1991).

Terör yönetimi kuramı, geleneksel sosyal psikoloji araştırmalarının çeşitli alanları için etkileri olan son derece geniş bir bakış açısı sunmaktadır. Kuramın en çekici yönlerinden biri sosyal davranışları anlamak için farklı etkilerinin olması ve test edilebilir hipotezlerinin geniş yelpazesidir (Rosenblatt, Greenberg, Solomon, Pyszczynski \& Lyon 1989). Terör yönetimi kuramı biyolojik ve psikolojik varsayımlara dayanmaktadır. Kuram benlik saygısı, adil dünya, bilişsel çelişki, sosyal kimlik ve izlenim yönetimi kuramlarını ve araştırmalarını bütünleştirmektedir (Baron 1997).

\section{Amac}

Türkiye'de terör yönetimi kuramını test eden sınırlı sayıda çalışma bulunmasına rağmen, son yıllarda bu çalışmalarda bir artış gözlenmektedir. Bu çalışmanın temel amacı Türkiye'de terör yönetimi kuramını ele almış çalışmaları derlemek ve meta analize tabi tutarak bir durum değerlendirmesi yapmaktır.

\section{Yöntem}

\section{Araştırma Modeli}

$\mathrm{Bu}$ çalışma, tarama yöntemi ve meta analize dayalı betimsel bir araştırmadır. Tarama çalışması birincil kaynaklar üzerinde yürütülmüştür. Balcı (2011), birincil kaynakları bilimsel dergilerde yer alan deneye dayalı araştırma ve makaleler, yüksek lisans ve doktora tezleri olarak ifade etmektedir. Meta analiz ise farklı zamanlarda, farklı konumlarda, farklı araştırmacılar tarafindan gerçekleştirilmiş olan çalışmaların istatistiksel olarak bütünleştirilmesini kapsamaktadır.

$\mathrm{Bu}$ çalışmada meta analize dâhil edilme ölçütleri terör yönetimi kuramına dayalı deney ve kontrol grubu olan, deney ve kontrol grubuna ait örneklem büyüklüğü, ortalaması ve standart sapması belli olan çalışmalar olarak belirlenmiştir. Bu kapsamda terör yönetimine ilişkin literatür bilgileri toplanarak çözümlenmiş ve çalışmanın amacı yönünde bütünleştirilmiştir. Böylece ülkemizde 2001-2014 yılları arasında terör yönetimi kuramını test eden 17 çalışmaya ulaşılmıştır. Bu çalışmaların 12 tanesi meta analiz yöntemiyle değerlendirilmiştir. 


\section{Verilerin Toplanması}

Araştırmada veriler kaynak taraması yoluyla toplanmıştır. Araştırmaya dâhil edilen çalışmalar 'terör yönetimi kuramı', 'dehşet yönetimi kuramı', 'ölümlülügün belirginliği', 'ölüm kaygısı', 'terror management theory', 'mortality salience' ve 'death anxiety' anahtar kelimeleriyle taranmiştır.

\section{Verilerin Analizi}

Verilerin analizinde 'Comprehensive Meta-Analysis' istatistiksel paket programı, etki büyüklügünün hesaplanmasında Hedges’in d'si kullanılmıştır.

\section{Bulgular}

Bulgular üç alt başlık altında sunulmuştur. Bunlar; literatür taraması sonuçları, terör yönetimi kuramı temelinde ülkemizde yapılmış olan çalışmaların sonuçları ve meta analiz sonuçlarıdır.

\section{A. Literatür Taraması Sonuçları}

İnsan davranışının birçok farklı alanında 'ölüm' konusu önemlidir. Ölümlülüğün farkındalığı sonucu oluşan kaygıyı kontrol etmede benlik saygısı ve kültürel dünya görüşü önemli bir rol oynamaktadır. Ölümün kaçınılmazlığı bilgisi sürekli hedef odaklı davranışı olanaksız kılmaktadır. Kuram bu terörün iki bileşenli kültürel kaygı tamponu tarafından yönetildiğini varsaymaktadır (Pyszczynski et al. 1997). Bunlar şu şekilde sıralanabilir:

1. Bireyin kültürel dünya görüşünün kişiselleştirilmiş şekli (dünyayı ve bireyin dünya içindeki yerini anlamak için bir dizi kavram, bireyin kişisel değer duygusu kazanabileceği standartlar dizisi ve bu standartlara uygun yaşayanlara ölümsüzlük vaadi)

2. Benlik saygısı veya kişisel değer duygusudur (kültürel dünya görüşünün parçası olan değer standartlarına uygun yaşamaya olan inancın kazanılması).

Ölümlülüğün belirgin hale getirilmesi, kültürel normlar ve değerler ön plana çıktığı zaman, sosyal normlara ve değerlere bağlılığı artırmaktadır. İnsanlar ölüm farkındalığını yönetmek için normlara ve değerlere bağlanmaktadırlar (Gailliot, Stillman, Schmeichel, Maner \& Plant 2008).

Terör yönetimi kuramı, insanların anlamlı bir dünyanın değerli üyeleri oldukları duygusunu sürdürmelerinin mümkün olmadığı durumlarda, bunun düşük benlik saygısı ile sonuçlanacağını önermektedir. Düşük benlik saygısı kültürel kaygı tamponunun bileşenlerinin korunmasındaki bir başarısızlığı yansıtmaktadır. Bazı durumlarda, bireyler kültürleri tarafından sağlanan dünya görüşünü kabul edebilirler, fakat sadece bu bağlamda kendilerini değerli olarak algılayamazlar. Benlik saygısının tehdit edilmesi bireyde kaygı yaratmaktadır. Birey bu kaygıyı azaltmak için farklı savunma stratejileri ile tepki vermektedir ve bu da kaygıy azaltmaktadır (Solomon et al. 1991).

Herhangi bir kültürel dünya görüşü nispeten kaygı içermeyen sembolik bir sosyal yapıdır (Solomon, Greenberg \& Pyszczynski 1991). Terör yönetimi kuramına göre, bireyin kültürel dünya görüşünü oluşturan inançlar ve değerler insan hassasiyetinin ve ölümlülüğünün farkındalı̆̆ından kaynaklanan kaygıyı tamponlama görevi olarak hizmet etmektedir. Herhangi bir birey tarafindan benimsenen kültürel dünya görüşü sürekli sosyal doğrulama gerektiren hassas bir yapıdır. Bu yüzden kuram, insanların kültürel kaygı tamponlarına destek olanlara olumlu ve kültürel kayg1 tamponlarını tehdit edenlere olumsuz tepki vereceklerini öne sürmektedir. Kurama göre kaygıdan korunmak için bireyin kültürel bağlamda benlik saygısı kazanması gerekmektedir (Rosenblatt et al. 1989).

Kültür, kültürel değerlerin standartlarına ulaşanları korumaktadır. Kültür bu korumayı iki 
yoldan sağlamaktadır. İlk olarak, dünya kavramını adil bir yer olarak tanımlamaktadır. Gerçek adil bir dünyada iyi insanlar kötü şeylerle karşılaşmamaktadırlar. İkinci olarak, kültürel değerlerin standartlarına ulaşanlara gerçek ve sembolik ölümsüzlük vaat edilmektedir. Kültürel dünya görüşleri öyle bir şekilde yapılandırılmıştır ki olumsuz sonuçlara karşı korunma ve ölümsüzlük duygusu kültürel gereklilikleri yerine getirmeye bağlıdır. Kültürel dünya görüşü bireyin kendisini anlamlı bir dünyada değerli bir katılımcı olarak düşünmesini ve böylece ölüm karşısında temkinli olarak işlev görmesini sağlayacak bir bağlam oluşturmaktadır (Rosenblatt et al. 1989).

Çağdaş toplumun karşılaştığı en yıkıcı ve kafa karıştırıcı sorunlardan biri insanların kendilerinden farklı olanlara karşı düşmanlık ve küçümseme ile tepki vermeleridir. Bireylere ölümlülükleri hatırlatılınca iç grup üyelerine karşı daha olumlu değerlendirmeler yaparken, diş grup üyelerine karşı daha olumsuz değerlendirmeler yapmaktadırlar (Greenberg et al. 1990).

Terör yönetimi kuramı bakış açısından bireylere ölümlülüklerinin hatırlatılması kültürel dünya görüşlerinin sağladığı kaygıdan korunma ihtiyacını artırmaktadır. Kültürel kaygı tamponu insanları altta yatan varoluşsal terörden korumaktadır. Ahlaki ihlallere karşı olumsuz tepkiler, böyle sapkınlıklar bireyin değerlerinin ve inançlarının geçerliliğini dolaylı olarak tehdit ettiği için ortaya çıkmaktadır. Ölümlülükleri hatırlatılan katılımcılar sürekli olarak ahlaki ihlallere karşı daha sert bir uygulama önermektedirler. Kültürel standartlardan sapan kişiler hor görülmektedir çünkü bu tür davranışlar bireyin güvenlik kaynağının temelinde yatan değerleri tehdit etmektedir. Benzer şekilde, kültürel değerleri koruyanlar takdir edilmektedirler; çünkü bu tür davranışlar bireyin değerlerini doğrulamaktadır (Rosenblatt et al. 1989).

Bireyin inançları ve değerleri diğerleri tarafından paylaşıldığında bu bireyin güvenini artırmaktadır. Diğer bireyler bireyin inançlarını ve değerlerini paylaşmadıkları zaman ise bireyin güveni tehdit edilmektedir. Bireyin diğer bireylere karşı tepkileri onun dünya görüşüne uymalarının ve uymamalarının etkilerine bağlıysa, insanların inançlarının kaygı tamponu olarak hizmet etmelerinden dolayı savunulması gerekiyorsa, insanlara en çok korktukları şeyin hatırlatılması kendilerine benzer kişilere karşı olumlu, kendilerinden farklı kişilere karşı olumsuz tepki verme eğilimlerini artıracaktır. Bu yüzden insanlara ölümlülükleri hatırlatıldığında kültürel dünya görüşlerini destekleyenleri olumlu, tehdit edenleri olumsuz değerlendireceklerdir (Greenberg et al. 1990).

Greenberg ve arkadaşları (1990) terör yönetimi kuramını sınamak için üç ayrı çalışma yapmışlardır. Çalışmalardan birinde ölümlülükleri hatırlatılan Hıristiyan katılımcılar diğer Hıristiyanları olumlu değerlendirirken, Yahudileri olumsuz değerlendirmişlerdir. İkinci çalışmada yüksek yetkecilik puanına sahip olan katılımcıların ölümlülükleri hatırlatıldığında düşük yetkecilik puanına sahip olanlara göre, kendilerine benzer olmayan bireyleri daha olumsuz değerlendirmişlerdir. Üçüncü ve son çalışmada ise ölümlülükleri hatırlatılan bireyler kültürlerini övenlere karşı olumlu, kültürlerini eleştirenlere karşı ise olumsuz tepki vermişlerdir. Ölümlülüğün hatırlatılması iç grup kayırmacılığını, farklı olanların reddedilmesini ve yetkecilik eğilimlerini artırmaktadır. Ölümlülük hatırlatıldığı zaman iç grup dayanışması, dış grup düşmanlığı, milliyetçilik, dinsel aşırılık, önyargı, ayrımcılık ve sapkınlığa karşı hoşgörüsüzlüğün artmas1 muhtemeldir.

Terör yönetimi kuramına göre, kendini koruma güdüsü (canlı kalma hedefi) tüm davranışların yönlendirildiği üst düzey bir hedeftir. Tüm diğer güdüler bir şekilde bu ana hedeften elde edilmiş ve bu hedefe hizmet etmektedirler. Hayatta kalmayı kolaylaştırmaya hizmet eden üç temel motivasyonel sistem önerilmiştir (Pyszczynski et al. 1997). Bunlar; doğrudan güdüler, sembolik (savunma) güdüler ve benlik genişleten güdülerdir. 
1. Doğrudan güdüler: Motivasyonel sistemin en temel koludur. İnsanları hayatta tutan biyolojik süreçler ve doğuştan gelen davranışsal eğilimlerdir (yeterli sıcaklık ve oksijenin sağlanması gibi). Kendini korumanın doğrudan araçları biyolojik öz düzenleyici sistemler olarak adlandırılmaktadır çünkü organizmanın varlığının devamını doğrudan ve basit bir şekilde kolaylaştırmaktadır.

2. Savunma güdüleri: Terör yönetimi kuramı bakış açısından anlamın ve değerin takibi veya kültürel dünya görüşü ve benlik saygısına olan inanç, olası terörle başa çıkmada birincil yoldur ve kendini korumanın sembolik araçları olarak adlandırılmaktadırlar. Bunlar bireyi hayatta tutmak için doğrudan bir etkiye sahip olmamalarına rağmen, ölümün kaçınılmazlığı bilgisinden kaynaklanan terörü kontrol etme işlevi görürler. İçsel homeostatik süreçler ve doğuştan gelen davranışsal eğilimler sosyal olarak anlamlı davranışlarda önemli bir rol oynamasına rağmen, anlam ve değer ihtiyacı olan sembolik terör yönetimi biyolojik eğilimlerimizin ifade ediliş biçimlerini belirlemektedir.

3. Benlik genişleten güdüler: Benlik genişleten güdüler hayatta kalmayı, karmaşık ve değişen çevreye uyum sağlayarak ve bu çevrede başarılı olmak için insan organizmasının kapasitesini geliştirerek kolaylaştırmaktadır. Terör yönetimi kuramı bakış açısından insanların çoğu olumlu benlik görüntülerini doğrulama peşindedirler çünkü bu benlik kavramı kaygıyı kontrol etmede bir rol oynamaktadır.

Terör yönetimi kuramının ilk deneysel testleri kuramdan türetilen iki temel hipoteze dayanmaktadır (Pyszczynski et al. 1997). Bunlar şöyle sıralanabilir:

1. Kaygı tampon hipotezine göre, eğer bir psikolojik yapı kaygıya karşı koruma sağlıyorsa, o yapının güçlendirilmesi sonucunda bireyin tehdit karşısında kaygı ve kaygı ile ilişkili davranış gösterme eğilimi daha az olacaktır. Bu yapının zayıflatılması bu eğilimi artıracaktır.

2. Ölümlülüğün belirginleşmesi hipotezine göre, eğer bir psikolojik yapı kaygıya karş1 koruma sağlıyorsa, insanlara bu kaygının kaynağının hatırlatılması bu yapıya olan ihtiyacı artıracaktır. $\mathrm{Bu}$ da sonuç olarak bunu destekleyenlere karşı olumlu, tehdit edenlere karşı ise olumsuz tepkilere yol açacaktır.

Kaygı tamponu ve ölüm belirginliği hipotezlerini test eden çalışmaların sonuçları benlik saygısı ve kültürel dünya görüşüne olan inancı güçlü bir şekilde desteklemektedir. En azından derinlemesine yerleşmiş ölüm korkusu ve güvenlik açığı için koruma sağlamaktadır (Pyszczynski, Greenberg \& Solomon 1999).

Çoğu kişi yaşamak istediklerinin ve kendi ölüm düşüncelerine karşı bazı duygusal tepkilere sahip olduklarının farkında olmalarına rağmen, terör yönetimi kuramı araştırmaları terör yönetimi savunmasını oluşturan kişilerarası duygu ve davranışlara götüren korku, kaygı veya terörün doğrudan duygusal deneyimden ziyade ölümle ilişkili düşüncelerin erişilebilirlikleri ile ilgili olduğunu göstermektedir. Bilinçdışı ölüm ile ilgili düşünceler erişilebilir hale geldikçe, benlik saygısı ve bireyin kültürel dünya görüşüne olan inancı tarafından sağlanan sembolik koruma ihtiyacı artmaktadır. Birey bu yapıları korumak ve tehditlere karşı kendisini savunmak için motive olacaktır. $\mathrm{Bu}$ süreçler aracılığıyla, ölüm ile ilgili bilinçdışı kaygılar, sosyal yargı ve davranış üzerinde geniş kapsamlı bir etkiye sahiptir (Pyszczynski et al. 1999).

\section{A- Terör Yönetimi Kuramı Temelinde Ülkemizde Yapılmış Olan Çalışmaların Sonuçları}

Tablo 1'de ülkemizde terör yönetimi kuramı temelinde yapılmış olan çalışmalar verilmiştir. 
Tablo 1. Türkiye'de Terör Yönetimi Kuramını Test Eden Çalışmalar

\begin{tabular}{|c|c|c|c|}
\hline & Yazar(lar) & Yıl & Örneklem Büyüklüğü \\
\hline 1 & Aslitürk & 2001 & 440 \\
\hline 2 & Şimşek & 2005 & 484 \\
\hline 3 & Aksüt-Çiçek & 2008 & 160 \\
\hline 4 & Bozo, Tunca ve Şimşek & 2009 & 100 \\
\hline 5 & Çamlı & \multirow{3}{*}{2010} & 208 \\
\hline 6 & Kökdemir ve Yeniçeri & & 60 \\
\hline 7 & Mert & & - \\
\hline 8 & Koca-Atabey ve Öner-Özkan & \multirow{4}{*}{2011} & 239 \\
\hline 9 & Atabey & & 115 \\
\hline 10 & Dalda & & 161 \\
\hline 11 & Uğurlar & & 141 \\
\hline 12 & Doğulu & 2012 & 185 \\
\hline 13 & Cihan & 2013 & 166 \\
\hline 14 & Güler & \multirow{4}{*}{2014} & 54 \\
\hline 15 & Kuzlak & & 186 \\
\hline 16 & Sözen & & 60 \\
\hline 17 & Çetiner & & - \\
\hline
\end{tabular}

Tablo 1'de görüldüğü üzere, ülkemizde terör yönetimi kuramını test etmek amacıyla literatür taramasının yapıldığ dır. Bu çalışmaların büyük bir kısmı tez çalışmalarını içermektedir. Kuram büyük çoğunlukla öğrenciler üzerinde test edilmiş olmasına rağmen öğrenciler dışında kalan farklı gruplardan katılımcılar da bulunmaktadır. Aynı zamanda son yıllarda bu alanda yapılmış olan çalışmaların artmış olduğu görülmektedir. Çalışmaların büyük bir kısmı psikoloji alanında gerçekleştirilmiştir. Bu çalışmaların 2 tanesi kısmi olmak üzere 12 tanesinin terör yönetimi kuramını desteklediği ve 2 tanesinin desteklemediği belirlenmiştir. Kalan 3 çalışma ise terör yönetimi kapsamındaki diğer çalışmalar başlığı altında ele alınmıştır.

\section{a) Terör Yönetimi Kuramını Destekleyen Çalışmalar}

Üniversite öğrencilerinin dindarlıkları ile saldırganlıkları arasındaki etkileşimi terör yönetimi kuramı çerçevesinde incelemiş olan Aksüt ve Çiçek (2008), dini eğilimleri tehdit edilen öğrencilerin ölümlülükleri hatırlatıldığında, saldırganlık eğilimlerinin artığını tespit etmiştir. Çamlı tarafından yapılan bir çalışmanın (2010) sonuçlarına göre, üniversitelerde başörtüsü serbestliğini destekleyen öğrencilerin ölümlülüğün hatırlatılmasının ardından kendilerine okumaları için verilen hem dini hem de laik görüşe ilişkin makaleyi olumlu değerlendirdikleri, liberal görüşe ilişkin makaleyi olumsuz olarak değerlendirdikleri tespit edilmiştir. Terör yönetimi sağlık modelini kadın katılımcılar üzerinde test etmiş olan Cihan'ın (2013) araştırmasının sonuçlarına göre, dış görünüşlerini toplumsal normlara göre değerlendirme eğiliminde olan kadın katılımcıların ölümlülükleri hatırlatıldığında zayıflama haplarına yönelik daha olumlu tutum bildirmiş oldukları tespit edilmiştir.

Güler bir çalışmasında (2014) dehşet yönetimi kuramı ve bazı sosyo-politik değişkenler açısından barışa ilişkin tutumları incelemiştir. Ölümlülüğün hatırlatılmasının ardından barışa ilişkin olumlu tutumların azalmış; siyasal güven, terörizm risk algısı ve sosyal baskınlık yönelimi düzeylerinin artmış olduğunu tespit etmiştir. Üniversite öğrencilerinin engel ve dehşet 
yönetimi temelinde kayıp kaygılarının incelenmiş olduğu bir çalışmanın katılımcılarına engel temelinde felç durumu; dehşet yönetimi temelinde ise, ölümlülük durumu hatırlatılmıştır. Sonuçlar, hem felç durumunun hem de ölümlülük durumunun bireylerde kaygı yarattığını göstermiştir (Atabey 2011).

Dalda (2011) ilişkiye bağlılık ve cinsiyetin ölüm kaygısına etkilerini incelemiştir. Eşlerinden ayrılmalarını hayal etmeleri istenen katılımcılardan eşlerine yüksek bağlılık gösterenlerin daha az ölüm kaygısı yaşadıkları saptanmıştır. Kökdemir ve Yeniçeri’nin (2010) terör yönetimi kuramını sınayan ilk çalışmalarında üniversite öğrencilerinin özel üniversite ve devlet üniversitesi hakkındaki kültürel dünya görüşleri test edilmiştir. İkinci çalışmada ise ölümlülük bilgisinin dini ve milliyetçi kimliğe etkisi araştırılmıştır. İlk çalışmanın sonucuna göre, özel üniversite öğrencilerinin devlet üniversitelerinin özel üniversitelere karşı üstünlüğünü savunan bir paragrafı daha olumsuz olarak değerlendirdikleri tespit edilmiştir. İkinci çalışmanın sonucuna göre ise katılımcıların Türkmenistan ile daha güçlü ilişkiler; İngiltere ve Yunanistan ile daha zayıf ilişkiler istedikleri saptanmıştır. Tüketici davranışlarını ve özellikle materyalist tüketimi terör yönetimi kuramı çerçevesinde incelemiş olan bir çalışmanın (Uğurlar 2011) sonucuna göre, ölümlülükleri hatırlatılan katılımcıların satın alma niyetlerinin artmış olduğu saptanmıştır. $\mathrm{Bu}$ çalışmada tüketim davranışı benlik saygısı arayışının bir parçası olarak düşünülmüştür.

Çetiner (2014)'in idari para cezası kararlarını terör yönetimi kuramı çerçevesinde incelemiş olduğu bir çalışmasının sonucuna göre, ölümlülüğü hatırlatılan jandarma personelinin ve jandarma okulu öğrencilerinin idari para cezası miktarının artması gerektiğini öne sürdükleri tespit edilmiştir. Bozo, Tunca ve Şimşek'in (2009) sağlığı destekleyen davranışların ölüm kaygısına etkilerini terör yönetimi kuramı çerçevesinde incelemiş oldukları çalışmada, ölümlülükleri hatırlatılan katılımcıların sağlığı destekleyen daha fazla davranış bildirmiş oldukları saptanmıştır.

\section{b) Terör Yönetimi Kuramını Kısmi Olarak Destekleyen Çalışmalar}

Kuzlak'ın (2014) dehşet yönetimi yaklaşımı ile Türkiye'deki futbol taraftarları arasındaki basmakalıp yargıları incelemiş olduğu çalışmasında ölümlülükleri hatırlatıldığında katılımcıların karşı takım taraftarlarına karşı daha fazla olumlu basmakalıp yargıda bulunmuş oldukları saptanmıştır. Yine, ölüm belirginliğinde bir takımı destekleyenler, aynı takım taraftarlarına karşı daha olumlu basmakalıp yargıda bulunmuşlardır. Ölüm belirginliğinin basmakalıp yargıyı artırmakta olduğu fakat bu etkinin her takım ve her basmakalıp yargı için geçerli olmadığı saptanmıştır. Koca-Atabey ve Öner-Özkan'ın (2011) savunmacı dini yönelime karşı varoluşsal dini yönelim ve ölüm belirginliği hipotezini incelemiş oldukları çalışmada ölümlülükleri hatırlatıldığında, savunmacı dini yönelime sahip katılımcıların daha muhafazakâr olduklarını, varoluşsal dini yönelime sahip katılımcılar için ise ölümlülüğün hatırlatılmasının herhangi bir etkisinin olmadığı saptanmıştır.

\section{c) Terör Yönetimi Kuramını Desteklemeyen Çalışmalar}

Sistemi meşrulaştırma kuramı ve terör yönetimi kuramı arasındaki ilişkiyi gruplararası ilişkiler ve cinsiyet bağlamında incelemiş olan bir araştırmanın (Doğulu 2012) sonuçlarına göre, ölümlülüğün hatırlatılmasının toplumsal cinsiyete bağlı sistemi meşrulaştırmada düzenleyici rolünün olmadığı saptanmıştır. Aynı şekilde, futbol fanatizmi, takımla özdeşleşme ve takıma psikolojik bağl1lık düzeylerini terör yönetimi kuramı çerçevesinde değerlendirmiş olan bir çalışmanın sonuçlarına göre katılımcıların ölümlülüklerinin hatırlatılmasının anlamlı bir etkisinin olmadığı tespit edilmiştir (Sözen 2014). 


\section{d) Terör Yönetimi Kuramı ile ilgili Diğer Çalışmalar}

Mert (2010) çalışmasında terör yönetimi kuramı hakkında bilgi vermiş ve kuramın geliştirilmesine katkı sağlamıştır. Kuramın temel kabullerini açıklamış ve kurama yöneltilen eleştirileri incelemiştir. Terör yönetimi kuramına yöneltilen eleştiriler temelinde cesaret kavramının bu eleştirilere cevap verebileceğini savunmuştur. Şimşek (2005)'in ölüm korkusundan öznel iyilik haline giden yolları terör yönetimi kuramına dayalı olarak incelemiş olduğu çalışmasında bağlanmanın, ölüm korkusu ve benlik saygısı ve kültürel dünya görüşünün uzaktan savunması arasında aracı bir değişken olduğu tespit edilmiştir. Terör yönetimi kuramını kolektif bir kültürde incelemiş olan bir çalışmanın (Aslıtürk 2001) sonucuna göre, kolektif özsaygının, kolektif ya da karşılıklı bağımlı benlik yapılarına sahip bireylerde ölümlülük korkusuna karşı koruyucu bir etki göstermediği tespit edilmiştir.

\section{B- Meta Analiz Sonuçları}

Türkiye'de terör yönetimi kuramını test eden 17 çalışmanın 12'si meta analize dâhil edilmiştir. Bu 12 çalışmanın toplam örneklem büyüklüğü 1903'tür. Tablo 2'de meta analize dahil edilmiş olan çalışmalar kodlanmıştır.

Tablo 2. Meta Analize Dahil Edilmiş Olan Çalışmaların Kodlanması

\begin{tabular}{|l|c|c|c|c|c|c|c|}
\hline & $\begin{array}{c}\text { Yayınlan- } \\
\text { ma Y1lı }\end{array}$ & $\begin{array}{c}\text { Yayın } \\
\text { Türü }\end{array}$ & $\begin{array}{c}\text { Yayınlanma } \\
\text { Durumu }\end{array}$ & $\begin{array}{c}\text { Deney } \\
\text { Grubu N }\end{array}$ & $\begin{array}{c}\text { Katılımc1 } \\
\text { Cinsiyeti }\end{array}$ & $\begin{array}{c}\text { Katılımc1 } \\
\text { Yaş } \\
\text { Ortalaması }\end{array}$ & $\begin{array}{c}\text { Manipülasyon } \\
\text { Tekniği }\end{array}$ \\
\hline Aslıtürk & 1 & 1 & 1 & 3 & 2 & 1 & 2 \\
\hline Aksüt-Çiçek & 2 & 1 & 2 & 2 & 2 & - & 1 \\
\hline Bozo et al. & 2 & 3 & 2 & 1 & 2 & 4 & 2 \\
\hline Çamlı & 2 & 1 & 2 & 3 & 2 & 1 & 1 \\
\hline Kökdemir et al. & 2 & 3 & 2 & 1 & 2 & 1 & 1 \\
\hline Atabey & 3 & 2 & 2 & 2 & 2 & 1 & 1 \\
\hline Dalda & 3 & 1 & 2 & 2 & 2 & 3 & 1 \\
\hline Uğurlar & 3 & 1 & 2 & 3 & 2 & 1 & 1 \\
\hline Doğulu & 3 & 1 & 2 & 2 & 2 & 2 & 1 \\
\hline Güler & 3 & 1 & 2 & 1 & 2 & 2 & 1 \\
\hline Kuzlak & 3 & 1 & 2 & 2 & 2 & 1 & 2 \\
\hline Sözen & 3 & 1 & 2 & 1 & & 2 & 1 \\
\hline
\end{tabular}

Tablo 2'de görüldügü üzere farklı kodlama türleri yapılmıştır. Kodlama yapılan çalışmalar deneysel olan çalışmalar ve yazar tarafından kullanımı kısıtlanmamış olan çalışmalardır. Yayınlanma yılı olarak 2000-2005 yılları aras1 1; 2006-2010 yılları aras1 2 ve 2011-2014 y1llar1 aras1 3 şeklinde kodlanmıştır. Yayın türü olarak yüksek lisans tezleri 1; doktora tezleri 2 ve makaleler 3 şeklinde kodlanmıştır. Yayınlanma durumunda yayınlanmamış çalışmalar 1; yayınlanmış çalışmalar ise 2 olarak kodlanmıştır. Deney grubu örneklem büyüklüğü $\leq 501 ; 51$ 100 arası 2 ve 101 ve üzeri 3 olarak kodlanmıştır. Katılımcı cinsiyeti erkek 1; kadın ve erkek 2 olarak kodlanmıştır. Katılımcı yaş ortalaması 20-23 yaş arası 1 olarak; 23.1-26.1 yaş arası 2 olarak; 26.2-29.2 yaş arası 3 olarak; 29.3 ve üzeri 4 olarak kodlanmıştır. Aksüt-Çiçek' in (2008) çalışmasında katılımcıların yaş ortalaması belirtilmemiştir. Manipülasyon tekniği olarak açık uçlu soruların kullanıldığı durumlar 1 ve ölüm kaygısı ölçeğinin kullanıldığı durumlar 2 
şeklinde kodlanmıştır.

Meta analize katılan çalışmaların yüzde ve frekansları Tablo 3'te verilmiştir.

Tablo 3. Kodlanmış Değişkenler için Yüzde (\%) ve Frekanslar (f) (n=12)

\begin{tabular}{|c|c|c|c|c|c|}
\hline & & \multicolumn{4}{|c|}{ Kodlamalar } \\
\hline & & 1 & 2 & 3 & 4 \\
\hline \multirow{2}{*}{ Yayınlanma Yılı } & $\mathrm{f}$ & 1 & 4 & 7 & \\
\hline & $\%$ & 8,33 & 33,33 & 58,34 & \\
\hline \multirow{2}{*}{ Yayın Türü } & $\mathrm{f}$ & 9 & 1 & 2 & \\
\hline & $\%$ & 75 & 8,33 & 16,67 & \\
\hline \multirow{2}{*}{ Yayınlanma Durumu } & f & 1 & 11 & & \\
\hline & $\%$ & 8,33 & 91,67 & & \\
\hline \multirow{2}{*}{ Deney Grubu N } & $\mathrm{f}$ & 4 & 5 & 3 & \\
\hline & $\%$ & 33,33 & 41,67 & 25 & \\
\hline \multirow{2}{*}{ Katılımcı Cinsiyeti } & f & 1 & 11 & & \\
\hline & $\%$ & 8,33 & 91,67 & & \\
\hline \multirow{2}{*}{ Katılımeı Yaş Ortalaması } & $\mathrm{f}$ & 7 & 2 & 1 & 1 \\
\hline & $\%$ & 58,34 & 16,67 & 8,33 & 8,33 \\
\hline \multirow{2}{*}{ Manipülasyon Tekniği } & $\mathrm{f}$ & 9 & 3 & & \\
\hline & $\%$ & 75 & 25 & & \\
\hline
\end{tabular}

Tablo 3'te görüldüğü üzere meta analize dahil edilen çalışmaların \%8,33'ü 2000-2005; \%33,33'ü 2006-2010 ve \%58,34'ü 2011-2014 yılları arasında yayınlanmıştır. Çalışmaların \%75'i yüksek lisans tezi; \%8,33'ü doktora tezi ve \%16,67'si makaledir. Çalışmaların \%8,33'ü yayınlanmamış ve \%91,67'si yayınlanmıştır. Çalışmaların \% 33,33'ü 50'den küçük; \%41,67'si 51 ile 100 arasında ve \%25'i 101 ve üzeri örneklem büyüklüğüne sahiptir. Katılımcıların \% 8,33'ünü sadece erkekler oluştururken, \%91,67'sini hem erkek hem kadınlar oluşturmaktadır. Katılımcıların $\% 58,34$ 'ünün yaş ortalamas1 20-23; \%16,67'sinin 23,1-26,1; \%8,33'ünün 26,2-29,2 ve $\% 8,33$ 'ünün 29,3 ve üzeridir. Çalışmaların \%75'inde manipülasyon tekniği olarak açık uçlu sorular ve \%25'inde ölüm kaygısı ölçeği kullanılmıştır.

Meta analize katılan çalışmaların etki büyüklükleri, standart hata değerleri, \% 95 güven aralığına göre alt ve üst limitleri ve p değerleri Tablo 4'te verilmiştir.

Tablo 4. Çalışmaların Etki Büyüklükleri, Standart Hata Değerleri, Alt ve Üst Limitleri ve p Değerleri

\begin{tabular}{|l|c|c|c|c|c|}
\hline & \multicolumn{4}{|c|}{} & \multicolumn{2}{|c|}{ \% 95 Güven Aralı̆̆ } & \\
\cline { 2 - 6 } & $\begin{array}{c}\text { Hedges'in Etki } \\
\text { Büyüklüğ̈̈ }\end{array}$ & Standart Hata & Alt Limit & Üst Limit & p \\
\hline Güler, 2014 & $-0,995$ & 0,289 & $-1,560$ & $-0,429$ & 0,001 \\
\hline Kökdemir et al. 2010 & $-0,641$ & 0,265 & $-1,160$ & $-0,122$ & 0,015 \\
\hline Ŭğurlar, 2011 & $-0,204$ & 0,119 & $-0,438$ & 0,030 & 0,088 \\
\hline Kuzlak, 2014 & $-0,115$ & 0,147 & $-0,403$ & 0,172 & 0,432 \\
\hline Sözen, 2014 & 0,093 & 0,258 & $-0,412$ & 0,601 & 0,714 \\
\hline Dalda, 2011 & 0,206 & 0,158 & $-0,104$ & 0,516 & 0,193 \\
\hline Asliturk, 2001 & 0,225 & 0,092 & 0,045 & 0,406 & 0,015 \\
\hline Doğulu, 2012 & 0,327 & 0,148 & 0,037 & 0,617 & 0,027 \\
\hline Camli, 2010 & 0,400 & 0,140 & 0,125 & 0,675 & 0,004 \\
\hline Atabey, 2011 & 0,443 & 0,194 & 0,063 & 0,823 & 0,022 \\
\hline Aksut-Cicek, 2008 & 0,818 & 0,165 & 0,495 & 1,141 & 0,000 \\
\hline Bozo et al. 2009 & 1,055 & 0,213 & 0,636 & 1,473 & 0,000 \\
\hline
\end{tabular}


Tablo 4'te etki büyüklükleri küçükten büyüğe doğru sıralanmıştır. Tabloda görüldüğü üzere etki büyüklükleri $-0,995$ ile 1,055 arasında değişmektedir. 8 çalışmada istatistiksel olarak anlamlı fark bulunmuş ( $p<0,05), 4$ çalışmada anlamlı bir fark bulunamamıştır. 8 çalışma olumlu ve 4 çalışma olumsuz etki büyüklüğüne sahiptir. Bu bulgular, çoğu durumda $(n=8)$ terör yönetimi kuramı hipotezlerinin etkili olduğunu daha az durumda $(\mathrm{n}=4)$ ise etkisinin olmadığını göstermektedir. Cohen (1982) etki büyüklüğünü $0,20-0,50$ küçük; $0,50-0,80$ orta; 0,80 ve üzeri geniş olarak kabul etmiştir. En yüksek etki büyüklüğüne sahip olan çalışma Bozo'nun et al. (2009), en düşük etki büyüklügüne sahip olan çalışma Güler'in (2014) çalışmasıdır. Etki büyüklüğü olumlu olan 8 çalışmadan 6'sı küçük ve 2'si geniş etki büyüklüğüne sahiptir.

Sabit etkiler modeli etki büyüklükleri arasındaki değişkenliğin örnekleme hatasından kaynaklandığını varsaymaktadır. Rastgele etkiler modeli etki büyüklükleri arasındaki değişkenliğin örnekleme hatası ve evren değişkenliğinden kaynaklandığını varsaymaktadır (Lipsey \& Wilson 2001). Rastgele etkiler modeline göre birleştirilmiş bulgular Tablo 5'te verilmiştir.

Tablo 5. Çalışmaların Rastgele Etkiler Modeline göre Birleştirilmiş Bulguları

\begin{tabular}{|l|c|c|c|c|c|}
\hline & Etki Büyüklüğü (d) & Standart Hata & Alt Sınır & Üst Sınır & $\mathbf{p}$ \\
\hline Rastgele Etkiler & 0,162 & 0,125 & $-0,083$ & 0,407 & 0,195 \\
\hline
\end{tabular}

Tablo 5'te görüldüğ̈̈ üzere, rastgele etkiler modeline göre toplam etki büyüklüğü $0,162(0,125$ standart hata ve güven aralığ $\% 95$, alt sınır $-0,083$ ve üst sınır 0,407 ) olarak saptanmıştır. Bu da Cohen (1982)'e göre küçük etki büyüklüğü olarak kabul edilmektedir.

Meta analize dahil edilmiş olan çalışmaların homojenlikleri test edilmiş ve bulgular Tablo 6 ' da verilmiştir.

Tablo 6. Çalışmaların Homojenliklerinin Test Edilmesi

\begin{tabular}{|c|c|c|}
\hline $\mathbf{Q}$ & $\mathbf{S D}(\mathbf{Q})$ & $\mathbf{p}$ \\
\hline 77,985 & 11 & 0,000 \\
\hline
\end{tabular}

Tablo 6'da etki büyüklüğü dağılımının homojenlik testi sonuçları verilmiştir. Tabloda görüldüğü üzere $\mathrm{p}<0,05$ olduğu için dağ 11 m homojen değildir. $\mathrm{P}$ değeri düşük olduğu için çalışmaların bulguları arasındaki farklar ihmal edilemez. Çalışmanın sonuçları heterojen olarak düşünülmelidir. Homojen olmadığı için sabit etkiler modeli yerine rastgele etkiler modeli kullanılmıştır (Akgöz, Ercan \& Kan 2004).

Orwin'in Fail-Safe N ile bu meta analiz çalışmasında eksik olan çalışma sayısı hesaplanmıştır (Borenstein, Hedges, Higgins \& Rothstein 2009). Yapılan meta analiz sonucunu geçersiz kılmak için manidar olmayan 33 çalışmaya daha ihtiyaç vardır. Ülkemizde bu alanda sınırlı sayıda çalışma olduğu için 33 çalışmaya daha ulaşılma olasılığı bulunmamaktadır. Bu da meta analizde yayın yanlılığı olmadığının bir göstergesidir.

Grafik 1'de etki büyüklüğü huni saçılım grafiği verilmiştir.

Grafik 1. Etki büyüklüğü huni saçılım grafiği 


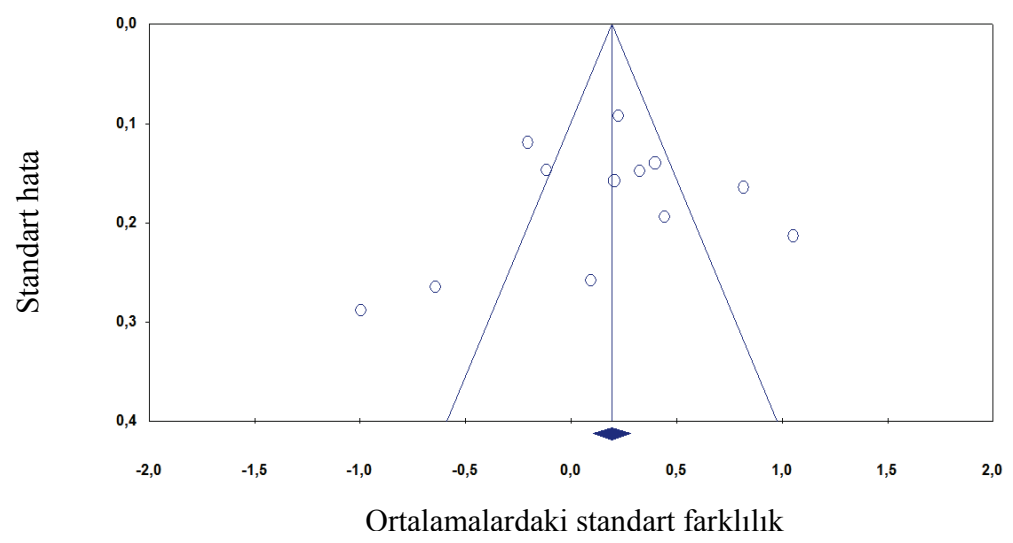

Grafik 1'de huni saçılım grafiği yayın yanlılı̆ğ olasılı̆̆ını göstermektedir. Yayın yanlılığ1 olasılığ 1 için asimetriklik beklenmektedir. Grafik 1'de asimetriklik gözlenmemektedir. Huni saçılım grafiğginin yanı sıra örneklemin yanlı olup olmadığını belirlemek için Kendall'ın Tau b katsayısı kullanılır. Bu çalışmada meta analize dahil edilen araştırmaların örneklemlerinin yanlı olmadığı anlaşılmaktadır (tau $b=-0,09 ; p>0,05)$.

\section{Tartışma ve Sonuç}

Terör yönetimi kuramı ülkemizde üzerinde sınırlı sayıda çalışma yapılmış olan bir araştırma alanıdır. Buna rağmen, bu alan son yıllarda büyük ilgi görmeye başlamıştır. Ülkemizde son 14 y1l (2001-2014) içerisinde bu alanda toplam 17 çalışma bulunmaktadır.

Ülkemizde yapılan çalışmalara bakıldığında terör yönetimi kuramını destekleyen 10, kısmi olarak destekleyen 2 ve desteklemeyen 2 çalışma bulunmaktadır. Terör yönetimi kuramı alanında diğer başlığı altında 3 çalışma bulunmaktadır. Genel anlamda terör yönetimi kuramını destekleyen çalışmalar çoğunluktadır ( $\mathrm{n}=10)$.

Terör yönetimi kuramının hipotezlerini test eden 12 çalışma meta analize dahil edilmiştir. Bu 12 çalışmada toplam örneklem büyüklüğü 1903'tür. Çalışmaların 8'inde istatistiksel olarak anlamlı bir fark bulunmuş iken 4 çalışmada anlamlı bir fark bulunamamıştır. Rastgele etkiler modeline göre toplam etki büyüklüğü $0,161(0,125$ standart hata ve güven aralığı $\% 95$, alt sınır 0,083 ve üst sınır 0,407) olarak saptanmıştır. Bu da Cohen (1982)'e göre küçük etki büyüklüğü olarak kabul edilmektedir.

Çalışmalardaki bu farklı bulgular ülkemize özgü olan birçok faktöre yüklenebilir. Ülkemizde yapılmış olan çalışmalardaki farklı bulgular öncelikli olarak dini bağlamda açıklanabilir. Ülkemiz vatandaşının \%99,2'si Müslümandır ve İslamiyet ülkemizde baskın bir dindir (DİB 2014). Ülke vatandaşlarının büyük bir çoğunluğunun Müslüman olması bir etki olarak düşünülebilir. Müslümanların ölüm hakkındaki düşünceleri ve ölümden sonraki hayat hakkındaki düşünceleri bu sonuçları açıklamak için kullanılabilir. Doğu dinlerinin aksine, çoğu batı dinlerinde hayat 'bir kerelik' bir fenomen olarak görülmektedir. Buna ek olarak, ölüm varoluşun nihai sonu olarak düşünülmektedir. Doğu ve Batı dini felsefeleri arasındaki bu temel fark, terör yönetimi kuramının temel dayanağı olan ölümlülüğün teröre neden olacağı varsayımına karş1 çıkmış olabilir (Maheswaran \& Agrawal 2003).

Çalışmalardaki farklı bulguların diğer bir nedeni de ülkenin kültürü olabilir. Terör yönetimi kuramı çoğunlukla bireyci kültürlerde test edilmiştir. Bu kültürler, başta ekonomik olmak üzere birçok yönden Türk kültüründen farklıdır. Kültürel çeşitliliğin en iyi bilinen boyutu bireyciliktoplulukçuluktur. Türkiye'de karşılıklı bağımlılık egemendir ve ülkemiz toplulukçu bir kültür 
yapısına sahiptir (Hofstede 1980). Bireyci kültürlerin üyeleri kendilerini ayrı ve özerk birey olarak, toplulukçu kültürlerin üyeleri ise kendilerini başkalarıyla temelde bağlı olarak görmektedirler (Markus \& Kitayama 1991). Bireyci bakış açısına temel olan özerkliğe, bağımsızlığa ve kendini gerçekleştirmeye odaklanmadır (Oyserman, Coon \& Kemmelmeier 2002). Buna karşılık, toplulukçular kendilerini gruplarıyla beraber tanımlamaktadırlar. Bireyci kültürlerde kişisel ihtiyaçlar ve hedefler diğer ihtiyaçların ve hedeflerin üstündeyken; toplulukçu kültürlerde grubu memnun etmek için bireysel ihtiyaçlardan vazgeçilmiştir (Matsumoto \& Juang 2004). Bireycilik-Toplulukçuluk boyutlarındaki bu farklılıklar çalışmaların bulgularındaki farklılıkları açıklayabilir. Şimşek'in (2005) de belirtmiş olduğu gibi terör yönetimi kuramı bireyci olmayan toplumlarda geçerli olmayabilir.

Türkiye'de yapılmış olan çalışmalarda katılımcıların büyük bir çoğunluğunun kadınlardan oluştuğu dikkati çekmektedir. İnsan davranışlarındaki farklılıkların kökenleri temel olarak cinsiyetler arasındaki farklılıklarda veya sosyal yapıdaki kadın ve erkeğin farklılaşan konumlarinda yatmaktadır (Eagly \& Wood 1999). Bu nedenle, bulgulardaki farkl1lıklar cinsiyet temelinde açılanabilir.

Terör yönetimi kuramını desteklemeyen çalışmalarda ölümlülüğün hatırlatılmasının etki yaratmadığı düşünülebilir. Ölümlülüğün hatırlatılmasının etki yaratabilmesi için en olası durum, bireylerin bu etkilerin en az farkında oldukları zamandır. Bu, insanların terör yönetimi kuramına verdikleri oldukça yaygın tepkiyi açıklamaya yardımcı olabilir. İnsanlar nadiren ölüm hakkında düşünmektedirler. Ölüm hakkında düşünüldüğü zaman, bunun insanlar üzerinde hiçbir etkisi olmamakta veya çok az etkisi olmaktadır (Greenberg, Pyszczynski, Solomon, Simon \& Breus 1994).

Terör yönetimi kuramı Amerika Birleşik Devletleri, Kanada, Almanya, İsrail ve Hollanda gibi ülkelerde test edilmiş ve kuramı destekleyen sonuçlar bulunmuştur. Bu çalışmalarda ölümlülük manipülasyonu farklı yollarla yapılmıştır. Bunlar; katılımcıların ölümleri hakkındaki açık uçlu soruları, ölüm ölçeğini, cenaze evine yakınlığı ve kanlı kaza görüntülerini içermektedir (Greenberg, Solomon \& Pyszczynski 1997). Ülkemizde yapılmış olan çalışmalarda ölümlülüğün belirgin hale getirilmesi için yapılmış olan manipülasyon tekniklerine bakıldığında iki farklı yöntemin kullanıldığ 1 görülmektedir. Çoğunluk olarak kullanılan yöntem açık uçlu sorular ile ölümlülüğün belirgin hale getirilmesidir. Daha az kullanılan yöntem ise 'Ölüm Kaygıs1 Ölçeği’ni kullanmaktır. Çalışmalardaki farklı bulgular yöntem bağlamında değerlendirildiğinde, ölümlülük manipülasyonu için ölüm kaygısı ölçeğinin kullanılmış olduğu çalışmaların sonuçları kuramı desteklemektedir. Bu alanda ileride yapılacak olan çalışmalarda açık uçlu sorular yerine ölüm kaygısı ölçeğinin kullanılması önerilebilir.

Terör yönetimi kuramı çeşitli nedenlerden dolayı yararlı olabilir. İlk olarak, kuram belirli insan davranışlarını geniş bir yelpazede açıklamaktadır. İnsanların sorunları için mantıklı açıklamalar sağlamaktadır. İkinci olarak, kültürel örgütlerin dinamikleri ve işlevleri ve bireysel psikolojik süreçler arasında önemli bir kuramsal bağlantı sağlamaktadır. Üçüncü olarak, kuram sosyal davranışı düzenlemek için yararlı bir çerçeve sağlamaktadır. Dördüncü olarak, açıklayıcı ve bütünleştirici yararına ilaveten, kuram deneysel incelemeye tabii tutulabilecek yararlı ve ilginç hipotezleri oluşturmak için faydalıdır (Solomon et al. 1991).

Böyle bir çalışmanın ülkemizde daha önce yapılmamış olması terör yönetimi kuramı alanında yapılmış çalışmaların büyük resmini ortaya çıkarmış ve ileride yapılacak olan araştırmalar için yön gösterici olmuştur.

Araştırmaların sonuçlarındaki farklılıklar şansa, uygulamadaki farklılıklara veya örneklemler arasındaki farklılıklara bağlı olabilir. Bu farklı sonuçlar nedeni ile bu alanda farklı bağ- 
lamlarda daha fazla araştırma yapılması önerilmektedir. Yapılan çalışmalar incelendiğinde katılımcı olarak genel anlamda öğrencilerin kullanılmış olduğu görülmektedir. İleride yapılacak olan çalışmalarda öğrenciler dışında kalan grubun kullanılması sosyal psikoloji literatürüne, çalışanların kullanılması endüstri ve örgüt psikolojisi literatürüne yeni bir bakış açısı getirebilir.

\section{KAYNAKÇA}

Akgöz S., Ercan İ. \& Kan İ. (2004). "Meta- analizi”. Uludağ Üniversitesi Tip Fakültesi Dergisi 30/2 (2004) 107-112.

Aksut-Çiçek S. (2008). Dindarlık İle Saldırganlık Arasındaki Etkileşimin Terör Yönetimi Kuramı Çerçevesinde İncelenmesi, Yüksek Lisans Tezi. Mersin Üniversitesi, Sosyal Bilimler Enstitusü, Mersin.

Aslitürk E. (2001). A Test of Terror Management Theory in a Collectivistic Culture: Buffering Role of Collective Self-Esteem. Unpublished Master Thesis. METU Graduate School of Social Sciences, Ankara.

Atabey C. M. (2011). Disability Salience as an Indicator of Loss Anxiety: An Alternative Explanation for the Fundamental Fear of Human Beings. Doctorate Thesis. METU Graduate School of Social Sciences, Ankara.

Balcı A. (2011). Sosyal Bilimlerde Araştırma Yöntem, Teknik ve İlkeleri. Ankara 2011.

Baron R. M. (1997). "On Making Terror Management Theory Less Motivational and More Social". Psychological Inquiry 8/1 (1997) 21-58.

Borenstein M., Hedges L. V., Higgins J. P. T. \& Rothstein H. R. (2009). Introduction to Meta-Analysis. UK 2009.

Bozo O., Tunca A. \& Simsek Y. (2009). The effect of death anxiety and age on health-promoting behaviors: A terror-management theory perspective. The Journal of Psychology 143/4 (2009) 377-389.

Cihan B. (2013). The Effects of Mortality Salience and Body-Related Social Norms on Attitudes Towards Diet Pill. Master Thesis. METU Graduate School of Social Sciences, Ankara.

Cohen J. (1992). "Statistical Power Analysis". Direction in Psychological Science 1/3 (1992) 98-101.

Çamlı S. (2010). Attitudes Towards Allowance of Headscarf in the Universities: A Terror Management Perspective. Master Thesis. METU Graduate School of Social Sciences, Ankara.

Çetiner A. (2014). Olum Farkindalı̆ı̆ın Kabahatlar Kanununun Uygulanmasında Jandarma Personelinin Belirlediği İdari Para Cezası Kararlarına Etkisinin Dehşet Yönetimi Kuramı Açısından Değerlendirilmesi. Unpublished Master Thesis. Kara Harp Okulu Komutanlığı, Ankara.

Dalda B. (2011). The Effects of Relationship Commitment and Gender on Death-Anxiety Among Turkish Young Adults: A Terror Management Theory Perspective. Master Thesis. METU Graduate School of Social Sciences, Ankara.

DỉB (Diyanet İşleri Başkanlığı) (2014). Türkiye'de Dini Hayat Araştırması.

Doğulu C. (2012). System Justification and Terror Management: Mortality Salience as a Moderator of System Justifying Tendencies in Gender Context. Master Thesis. METU Graduate School of Social Sciences, Ankara.

Eagly A. H. \& Wood, W. (1999). "The origins of sex differences in human behavior". American Pscyhologist 54/6 (1999) 408-423.

Gailliot M. T., Stillman T. F., Schmeichel B. J., Maner J. K. \& Plant E. A. (2008). "Mortality Salience Increases Adherence to Salient Norms and Values". Personality and Social Psychology Bulletin 34 (2008) 993-1003.

Greenberg J., Pyszczynski T., Solomon S., Rosenblatt A., Veeder M., Kirkland S. \& Lyon D. (1990). "Evidence for Terror Manegement Theory II: The Effects of Mortality Salience on Reactions to Those who Threaten or Bolster the Cultural Worldview". Journal of Personality and Social Psychology 58/2 (1990) 308-318.

Greenberg J., Pyszczynski T., Solomon S., Simon L. \& Breus M. (1994). Role of Consciousness and 
Accessibility of Death-Related Thoughts in Mortality Salience Effects. Journal of Personality and Social Psychology 67/4 (1994) 627-637.

Greenberg J., Solomon S. \& Pyszczynski T. (1997). "Terror Management Theory of Self-Esteem and Social Behavior: Empirical Assessments and Conceptual Refinements". Advances in Experimental Social Psychology 29 (1997) 61-139.

Güler E. (2014). Barışa Iliskin Tutumlar: Dehşet Yonetimi Kuramı ve Bazı Sosyo-Politik Değişkenler Açısından Bir Inceleme. Yüksek Lisans Tezi. Ankara Üniversitesi Sosyal Bilimler Enstitüsü, Ankara 2014.

Hofstede G. (1980). Culture's Consequences: International Differences in Work-Related Values. Beverly Hills CA 1980.

Kalaoğlu-Özturk Z. (2000). Yaşlı Bireylerde Ölüm Kaygısı. Uzmanlık Tezi. Adana 2000.

Koca-Atabey M. \& Öner-Özkan B. (2011). "Defensive or Existential Religious Orientations and Mortality Salience Hypothesis: Using Conservatism as a Dependent Measure”. Death Studies 35/9 (2011) 852865.

Kokdemir D. \& Yeniceri Z. (2010). “Terror Management in a Predominantly Muslim Country”. European Psychologist 15/3 (2010) 165-174.

Kuzlak A. (2014). Stereotyping Among Football Fans in Turkey: A Terror Management Perspective. Master Thesis. METU Graduate School of Social Sciences. Ankara 2014.

Lipsey M. W. \& Wilson D. B. (2001). Practical Meta-Analysis. Thousand Oaks, CA.

Maheswaran D. \& Agrawal N. (2003). "Motivational and Cultural Variations in Mortality Salience Effects: Contemplations on Terror Management Theory and Consumer Behavior". Journal of Consumer Psychology 14/3 (2003) 213-218.

Markus H. R. \& Kitayama S. (1991). "Culture and the Self: Implications for Cognition, Emotion, and Motivation". Psychological Review 98 (1991) 224-253.

Matsumoto D. \& Juang L. (2004). Culture and Psychology. Belmont, CA 2004.

Mert İ. S. (2010). “Terör Yönetimi Kuramı ve Cesaret: Kavramsal Bir Tartışma”. Güvenlik Stratejileri Dergisi 6/12 (2010) 57-82.

Oyserman D., Coon H. M. \& Kemmelmeier M. (2002). "Rethinking Individualismand Collectivism: Evaluation of Theoretical Assumptions and Meta-Analyses". Psychological Bulletin 128 (2002) 3-72.

Pyszczynski T., Greenberg J. \& Solomon S. (1997). "Why Do We Need What We Need? A Terror Management Perspective on the Roots of Human Social Motivation". Psychological Inquiry 8/1 (1997) 1-20.

Pyszczynski T., Greenberg J. \& Solomon S. (1999). "A Dual-Process Model of Defense Against Conscious And Unconscious Death-Related Thoughts an Extension of Terror Management Theory". Psychological Review 106/4 (1999) 835-845.

Rosenblatt A., Greenberg J., Solomon S., Pyszczynski T. \& Lyon D. (1989). "Evidence for Terror Management Theory I: The Effects of Mortality Salience on Reactions to Those who Violate or Uphold Cultural Values". Journal of Personality and Social Psychology 57/4 (1989) 681-690.

Solomon S., Greenberg J. \& Pyszczynski T. (1991). “A Terror Management Theory of Social behaviour: The Psychological Functions of Self-Esteem and Cultural Worldviews". Advances in Experimental Social Psychology 24 (1991) 93-159.

Sözen A. I. (2014). Parasosyal Etkileşim, Terör Yönetimi Kuramı ve Futbol Fanatizmi. Yüksek Lisans Tezi. Ankara Üniversitesi Sosyal Bilimler Enstitüsü. Ankara 2014.

Şimsek O. F. (2005). Paths from Fear of Death to Subjective Well-Being: A Study of Structural Equation Modeling Based on the Terror Management Theory Perspective. Unpublished Master Thesis. METU Graduate School of Social Sciences. Ankara 2005.

Uğurlar N. P. (2011). Tüketici Davranışlarının Terrör Yönetimi Teorisi Çercevesinde Incelenmesi. Yüksek Lisans Tezi. Ege Üniversitesi Sosyal Bilimler Enstitusü. İzmir 2011. 